\title{
Biochemical characterization and cellular imaging of a novel, membrane permeable fluorescent CAMP analog Daniela Moll $^{\dagger 1}$, Anke Prinz ${ }^{* \dagger 1}$, Cornelia M Brendel ${ }^{2}$, Marco Berrera ${ }^{3}$, Katrin Guske ${ }^{1}$, Manuela Zaccolo ${ }^{3}$, Hans-Gottfried Genieser ${ }^{4}$ and Friedrich W Herberg1
}

\begin{abstract}
Address: ${ }^{1}$ University of Kassel, Department of Biochemistry, Heinrich-Plett-Strasse 40, 34132 Kassel, Germany, ${ }^{2}$ University of Kassel, Department of Physical Chemistry, Heinrich-Plett-Strasse 40, 34132 Kassel, Germany, ${ }^{3}$ University of Glasgow, University Avenue, Glasgow G12 8QQ, Scotland, UK and ${ }^{4}$ BIOLOG Life Science Institute, Flughafendamm 9a, P.O. Box 107125, Bremen, Germany

Email: Daniela Moll - daniela.moll@uni-kassel.de; Anke Prinz* - ankeprinz@uni-kassel.de; Cornelia M Brendel - cornelia.brendel@unikassel.de; Marco Berrera - m.berrera@bio.gla.ac.uk; Katrin Guske - katrin_guske@gmx.de; Manuela Zaccolo - M.Zaccolo@bio.gla.ac.uk; HansGottfried Genieser - hgg@biolog.de; Friedrich W Herberg - herberg@uni-kassel.de

* Corresponding author †Equal contributors
\end{abstract}

Published: 25 June 2008

BMC Biochemistry 2008, 9:18 doi:10.1186/147I-2091-9-18
Received: 28 january 2008

Accepted: 25 June 2008

This article is available from: http://www.biomedcentral.com//47I-209I/9//8

(c) 2008 Moll et al; licensee BioMed Central Ltd.

This is an Open Access article distributed under the terms of the Creative Commons Attribution License (http://creativecommons.org/licenses/by/2.0), which permits unrestricted use, distribution, and reproduction in any medium, provided the original work is properly cited.

\begin{abstract}
Background: A novel fluorescent cAMP analog (8-[Pharos-575]- adenosine-3', 5'-cyclic monophosphate) was characterized with respect to its spectral properties, its ability to bind to and activate three main isoenzymes of the cAMP-dependent protein kinase (PKA-I $\alpha$, PKA-II $\alpha$, PKA-II $\beta$ ) in vitro, its stability towards phosphodiesterase and its ability to permeate into cultured eukaryotic cells using resonance energy transfer based indicators, and conventional fluorescence imaging.
\end{abstract}

Results: The Pharos fluorophore is characterized by a Stokes shift of $42 \mathrm{~nm}$ with an absorption maximum at $575 \mathrm{~nm}$ and the emission peaking at $617 \mathrm{~nm}$. The quantum yield is $30 \%$. Incubation of the compound to RIl $\alpha$ and RII $\beta$ subunits increases the amplitude of excitation and absorption maxima significantly; no major change was observed with Rla. In vitro binding of the compound to Rl $\alpha$ subunit and activation of the PKA-l $\alpha$ holoenzyme was essentially equivalent to cAMP; RII subunits bound the fluorescent analog up to ten times less efficiently, resulting in about two times reduced apparent activation constants of the holoenzymes compared to cAMP. The cellular uptake of the fluorescent analog was investigated by cAMP indicators. It was estimated that about $7 \mu M$ of the fluorescent cAMP analog is available to the indicator after one hour of incubation and that about $600 \mu \mathrm{M}$ of the compound had to be added to intact cells to half-maximally dissociate a PKA type lla sensor.

Conclusion: The novel analog combines good membrane permeability- comparable to 8-Br-cAMP - with superior spectral properties of a modern, red-shifted fluorophore. GFP-tagged regulatory subunits of PKA and the analog co-localized. Furthermore, it is a potent, PDE-resistant activator of PKA-I and -II, suitable for in vitro applications and spatial distribution evaluations in living cells. 


\section{Background}

Fluorescent nucleotides have become widely utilized tools in basic research [1], and the number of corresponding reports on their use in cellular systems is vast. However studies involving the second messenger cAMP have not kept pace, and studies using fluorescently tagged cAMP analogs are still limited.

Early reports mainly used nucleobase-modified analogs where the purine ring system was part of the fluorophore, such as 1, N6- etheno-cAMP [2], 2- aza- 1, N6- ethenoCAMP [3] or the cyclic phosphate of 2- aminopurine riboside [4]. However, these compounds are far from being optimal with regard to membrane permeability, cAMPdependent protein kinase (PKA) binding affinity and stability towards phosphodiesterases (PDEs). Further more, the fluorophores lack brilliance and possess unfavorable spectral properties, e.g., excitation is to be performed in the UV range, which can be harmful to intact cells and monitoring of the relatively short emission wavelengths is often disturbed by intrinsic fluorescent components of the cell.

For studies involving PDEs, anthraniloyl [5]- and methylanthraniloyl- modified [6] CAMP (MANT-cAMP) have been introduced, where the ribose 2 - position carries a fluorescent reporter group. Since the 2 - modification render these structures unable to activate PKA, the MANT group has been linked to the positions 6 [7] and 8 [8] of the adenine nucleobase as well (MABA-cAMP). According to corresponding lipophilicity data $\left(\log \mathrm{k}_{\mathrm{w}}\right)$, cyclic nucleotides with MANT modification have improved membrane permeability and better PDE-resistance (at least 6- and 8modified structures), but are still suboptimal with respect to their spectral properties. The same holds true for cAMP modified with the NBD fluorophore (8-[2-[(7-Nitro-4benzofurazanyl)aminolethyl]thio]adenosine-3',5'-cyclic monophosphate; 8-NBD-cAMP) [6].

Fluorescein and rhodamine have been attached to the 8position of CAMP as well [9], however, in spite of the improved spectral properties of these dyes, both conjugates are not membrane permeable due to an additional charge within the dye moiety. Unfortunately, nearly all modern fluorescent dye structures contain positive or negative charges which support the electronic push/pull mechanism of the respective chromophore but render the corresponding conjugates rather polar, especially when attached to nucleotides with their polar phosphate groups. Even cAMP conjugates with state-of-the-art dyes such as Cy3 [10], Evoblue, and Bodipy ${ }^{\circledR}[11,12]$, which have excellent spectral properties, fail to pass cellular membranes, and require invasive application techniques like patch clamp or microinjection or the osmotic lysis of pinocytic vesicles [13] and are mainly utilized in vitro assays. Importantly, if these dyes are connected to the 2'ribose moiety, the resulting conjugates will not bind to and activate PKA anymore. Finally, phosphate-modified caged CAMP analogs have been described, which - upon photo-activation - release cAMP together with fluorescent coumarines [14,15].

Thus, in spite of quite a number of different fluorescent variants of CAMP, these structures have only limited application scopes, and presently no analog is available that offers improved properties in all important aspects mentioned, and which could be used with intact cells for tracking or intracellular imaging experiments.

The main effector enzyme of cAMP is the cAMP-dependent protein kinase (PKA), which reversibly phosphorylates substrate proteins. Protein kinases and their counter players, phosphatases and cAMP-degrading PDEs, are key regulatory enzymes in eukaryotic cells. PKA is a multi-substrate enzyme mediating the majority of the known effects of cAMP by regulating the activity of proteins involved in signal transduction, energy metabolism, cell proliferation, and differentiation [16]. In the absence of CAMP, all PKA isoforms consist of two regulatory $(\mathrm{R})$ and two catalytic subunits $(\mathrm{C})$ that form an inactive tetramer. Binding of at total of four cAMP molecules to the two tandem CAMP binding sites of each $\mathrm{R}$ subunit promotes the dissociation of the holoenzyme complex and leads to the release of the now active $\mathrm{C}$ subunits phosphorylating target proteins in the cytosol or in the nucleus [17]. Main isoforms of the $\mathrm{C}$ subunit are $\mathrm{C} \alpha, \mathrm{C} \beta, \mathrm{C} \gamma$ and PrKX, and several minor isoforms have been identified at least at cDNA level. In human, four different isoforms of the R subunit (RI $\alpha, \mathrm{RI} \beta$, RII $\alpha, \operatorname{RII} \beta$ ) have been identified [18].

Besides PKA and its corresponding signaling pathway, cAMP addresses additional cellular targets such as cyclic nucleotide-dependent ion channels (cyclic nucleotide gated ion channel and hyperpolarization-activated cyclic nucleotide-modulated channel) as well as the exchange protein directly activated by cAMP (Epac), which are worthwhile objects for evaluation with fluorescent analogs $[19,20]$.

In view of the importance of the CAMP messenger system, improved tools for a more detailed investigation of functions and receptor distribution would be quite helpful. Thus, in this study, the properties of a novel commercially available conjugate of cAMP with the Pharos dye, 8-[Pha-

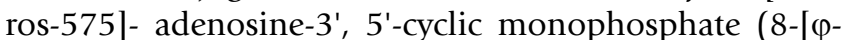
575]-cAMP) and the corresponding free dye were investigated and analyzed physico-chemically (spectral properties, stability), with respect to PKA-RI and -RII subunit binding as well as holoenzyme activation in vitro and in living cells, PDE-resistance, and cellular uptake. 


\section{Results and Discussion} Photochemical characterization of the Pharos dye

First we determined the photo-chemical properties of the free Pharos dye. The Stokes shift at pH 6.0, pH 7.0 and pH 7.4 was $42 \mathrm{~nm}$ resulting from an absorption maximum at $575 \mathrm{~nm}$ and an emission maximum at $617 \mathrm{~nm}$ (Fig. 1; $\left.\varepsilon_{575 \mathrm{~nm}}=15,650\right)$. 8-[ $\left.\varphi-575\right]$-cAMP behaved similarly with an excitation maximum at $577 \mathrm{~nm}$ and emission maximum at $605 \mathrm{~nm}$ at pH 7.0 (Fig. 2, and data not shown).

To calculate the relative quantum yield $\varphi$ of the Pharos dye the absorption (500 $\mathrm{nm}$ to $640 \mathrm{~nm}$ ) and fluorescence $\left(\lambda_{\text {ex }}=553 \mathrm{~nm}, \lambda_{\text {em }}\right.$ ranging from $558 \mathrm{~nm}$ to $\left.800 \mathrm{~nm}\right) \mathrm{spec}-$ tra of several Pharos dye concentrations (640 nM to 64.2 $\mu \mathrm{M}$ ) were recorded using quinine sulfate as a standard $[21,22]$. The determination of the relative quantum yield is generally accomplished by plotting the integrated fluorescence intensity versus the absorbance at the excitation wavelength (see Additional file 1, panel a). By comparing the slope of the linear regression (see Additional file 1, panel b) with that of a standard substance (quinine sulfate), the relative quantum yield of the Pharos dye was determined to be $30 \%$.

\section{Spectral properties of 8-[ $\varphi-575]-c A M P$ upon binding to PKA R-subunits}

8-[ $\varphi-575]$-cAMP was incubated with or without a fourfold molar excess of RI $\alpha$, RII $\alpha$ and RII $\beta$ subunits (Fig. 2). The excitation spectra (a) were detected at Em $617 \mathrm{~nm}$ and Ex $610 \mathrm{~nm}-430 \mathrm{~nm}$; the emission spectra (b) were detected at Ex $575 \mathrm{~nm}$ and Em $680 \mathrm{~nm}-580 \mathrm{~nm}$. Upon addition of RII $\alpha$ and RII $\beta$ subunits we observed an increase of the

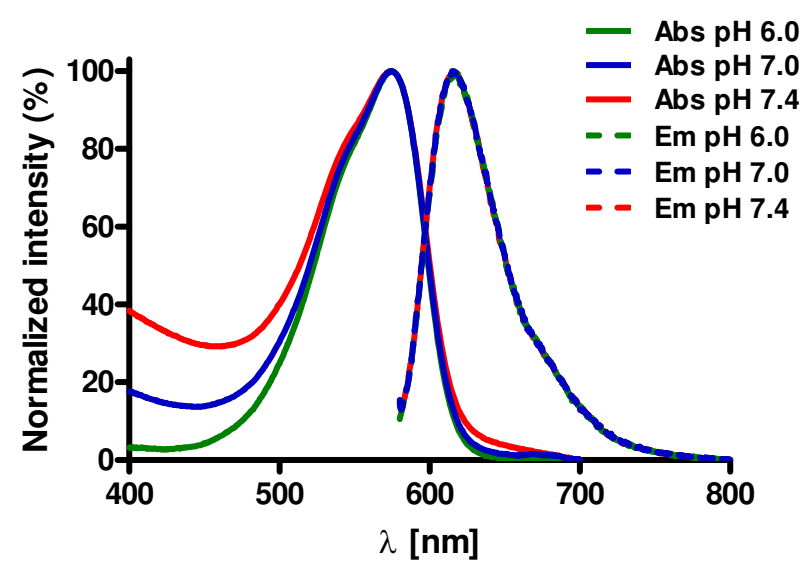

Figure I

Fluorescence absorption and emission spectra of the Pharos dye. The absorption maxima of the Pharos dye dissolved in buffer with the indicated pH values is at $575 \mathrm{~nm}$, whereas the emission maxima are at $617 \mathrm{~nm}$. All spectra exhibit a large Stokes shift of $42 \mathrm{~nm}$.

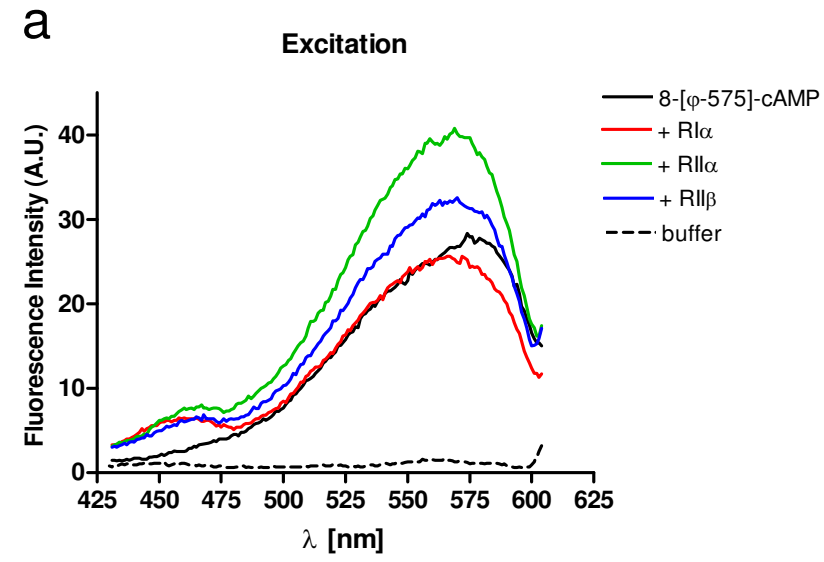

b Emission

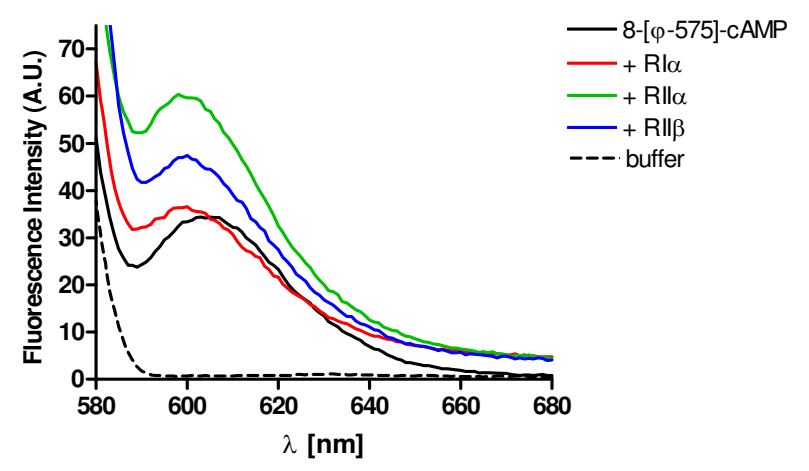

Figure 2

Fluorescence spectra of 8-[ $\varphi-575]-c A M P$ bound to PKA R subunits. $150 \mathrm{nM} 8-[\varphi-575]-c A M P$ was incubated with or without fourfold molar excess of PKA R subunits as indicated in the figure. The excitation spectra (a) were detected at $E m 617 \mathrm{~nm}$ and $E x 610 \mathrm{~nm}-430 \mathrm{~nm}$; the emission spectra (b) were detected at Ex $575 \mathrm{~nm}$ and Em $680 \mathrm{~nm}-580$ $\mathrm{nm}$. The experiments were repeated four times with similar results.

amplitude of excitation and emission maxima, whereas the interaction of the analog with RI $\alpha$ protein had no significant effect. Furthermore, a slight shift of the excitation and emission spectra to shorter wavelengths $(E x=570$ $\mathrm{nm}$; $\mathrm{Em}=600 \mathrm{~nm}$ ) was found with all three R subunits.

\section{8-[ $\varphi-575]-c A M P$ binding to PKA $R$ subunits and activation of PKA}

It has been shown that CAMP analogs, modified in position 8 of the adenine nucleobase, are powerful activators of protein kinase A, and even rather bulky substituents are accepted here. In addition, all analogs modified with fluorophores of high molecular weight and steric demands were reported to be potent PKA agonists[7]. 
To investigate the binding of 8-[ $\varphi-575]$-cAMP to RI and RII subunits, we employed a fluorescent polarization displacement assay using $2.5 \mathrm{nM}$ R subunit. Displacement of 8-Fluo-cAMP bound to the $\mathrm{R}$ subunits was followed by allowing either cAMP or 8-[ $\varphi-575]$-cAMP to compete with 8 -Fluo-cAMP binding. In the case of RI $\alpha$, we found $8-[\varphi-$ 575]-cAMP and cAMP bound equally well to the R subunit (Fig. 3a). In case of RII $\alpha$ and RII $\beta$, cAMP was about 10 times and 5 times more efficient in displacing 8-FluocAMP compared to $8-[\varphi-575]$-cAMP, respectively (Fig. 3b und 3c). With respect to both, isoform and site selectivity, and considering the bulky substituent in position 8 of the adenine nucleobase, it could have been expected that 8[ $\varphi$-575]-cAMP prefers the B- site of PKA type II. However, our data show that binding to RI $\alpha$ is comparable to CAMP,

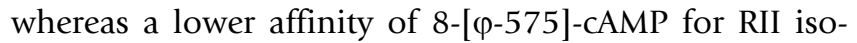

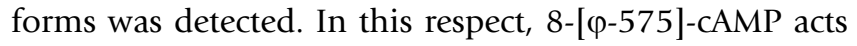
similar to 8-Fluo-cAMP, which shows rather high affinity for the site BII along with rather lower affinity to AII, but a quite equal binding capacity to both sites A and B of RI, thus resulting in an overall higher binding to RIa [23], analogous to other 8-substituted analogs $[24,25]$.

We next investigated the ability of 8-[ $\varphi$-575]-cAMP to activate PKA-I and -II holoenzymes side by side. RI $\alpha$, RII $\alpha$ and RII $\beta$ each were allowed to form a holoenzyme complex with the C $\alpha$ subunit, before adding increasing amounts of either cAMP or 8-[ $\varphi$-575]-CAMP to re-activate the C $\alpha$-subunit. Kinase activity was assayed spectrophotometrically [26], using the synthetic heptapeptide Kemptide as a substrate. The binding properties of $8-[\varphi-575]$-cAMP to the RI $\alpha$ subunit is reflected in a nearly identical activation titration curve and corresponding activation constant comparing analog $\left(\mathrm{EC}_{50}=150 \mathrm{nM}\right)$ with $\operatorname{cAMP}\left(\mathrm{EC}_{50}=\right.$ $120 \mathrm{nM},[27,28]$, Fig. 4a). However, activation of RII $\alpha$ and RII $\beta$ holoenzymes was less cooperative using 8-[ $\varphi-575]$ CAMP, indicated by a more shallow hill slope of the activation titration curves (Fig. 4a and $4 \mathrm{~b}$ ). The corresponding apparent activation constants $\left(\mathrm{EC}_{50}\right.$-values) were about two-fold increased for 8-[ $\varphi-575]$-cAMP compared to $\operatorname{cAMP}\left(\mathrm{EC}_{50} \mathrm{RII} \alpha=280 \mathrm{nM} ; \mathrm{EC}_{50} \mathrm{RII} \beta=900 \mathrm{nM}\right)$.

\section{Uptake of 8-[ $\varphi-575]-c A M P$ in living cells and activation of PKA}

Insights into the intracellular distribution within eukaryotic cells were obtained by intracellular imaging of the cyclic nucleotide analog. 8-[ $\varphi-575]$-cAMP clearly enters the cultivated HEK293 and CHO cells. In most cases it displays a spotty distribution inside the cells and seems to accumulate in bright aggregates over a diffusely labeled background. The nuclear compartment was unlabeled in most cells (Fig. 5a and 5b). In some experiments, employing COS-7 cells less than 5\% of the cells showed an accumulation of the compound in the nucleus, which might be attributable to apoptotic degeneration of the cells (data not shown). Variations in the incubation procedure (e.g. decrease in temperature, addition of pluronic ${ }^{\circledast}$ or serum during incubation $[29,30]$ ) did not significantly change the distribution pattern or the accumulation in bright spots. However, an incubation temperature of $4{ }^{\circ} \mathrm{C}$ led to a markedly reduced uptake and accumulation of the compound (data not shown). This could indicate that membrane trafficking, which is inhibited at $4^{\circ} \mathrm{C}$, is part of the accumulation process. Whether pinocytotic uptake of the compound or exocytotic processes involving cAMP are inhibited [31], deserves further study. The free Pharos dye efficiently diffuses within the cells and does not accumulate in spots like $8-[\varphi-575]$-cAMP does (Fig. $5 \mathrm{c}$ and $5 \mathrm{~d}$ ).

It has previously been shown that fluorescent cAMP analogs were able to label RI $\alpha$ aggregates, respectively [3234]. We therefore investigated whether the compound colocalizes with GFP-tagged RI $\alpha$ and RII $\alpha$ proteins expressed in COS-7 cells, and indeed we found co-localization of 8$[\varphi-575]$-cAMP, but not the free dye, with R subunits (Fig. 6 , and data not shown), indicating that the accumulation of the fluorescent CAMP might be in part due to association to (clustered) cAMP binding proteins. However, we can not entirely exclude unspecific aggregation of $8-[\varphi-$ 575]-CAMP.

In contrast to many other modern fluorophores, the Pharos chromophore has considerably reduced bulkiness along with high lipophilicity. Thus, $8-[\varphi-575]$-cAMP has a lower molecular weight compared to e.g. fluoresceinmodified-cAMP (8-[2-[(Fluoresceinylthioureido) amino]ethyl]thio]adenosine-3', 5'-cyclic monophosphate; 8-Fluo-cAMP). Due to its merely hydrophobic character, the dye has a big impact on the analog overall lipophilicity, which in turn should compensate the negative charge of the cyclic phosphate and finally lead to good membrane permeability of 8 -[ $\varphi-575]$-cAMP. In lipophilicity measurements using reversed phase HPLC [35], its $\log K_{w}$ was determined to be 2.95 resulting in a more than 70 times increased lipophilicity compared to CAMP (data not shown). In this respect the analog resembles highly membrane-permeant PKA agonists such as Sp5,6-DCl-cBIMPS [36] or the Epac activator 8-pCPT-2'-OMe-cAMP [37], and surpasses all fluorescent CAMP analogs described so far. We therefore investigated the kinet-

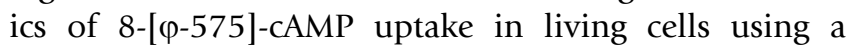
genetically encoded fluorescent indicator $(\mathrm{H} 30)$ formed by a cAMP binding domain from Epac and two spectral variants of the green fluorescent protein (GFP) [38]. Its functioning is based on the phenomenon of fluorescence resonance energy transfer (FRET). FRET relies on a nonradiative, distance-dependent transfer of energy between the two fluorescent domains: by exciting the first, the emission from the second one can be detected. Since FRET depends on the distance between the two fluorophores 


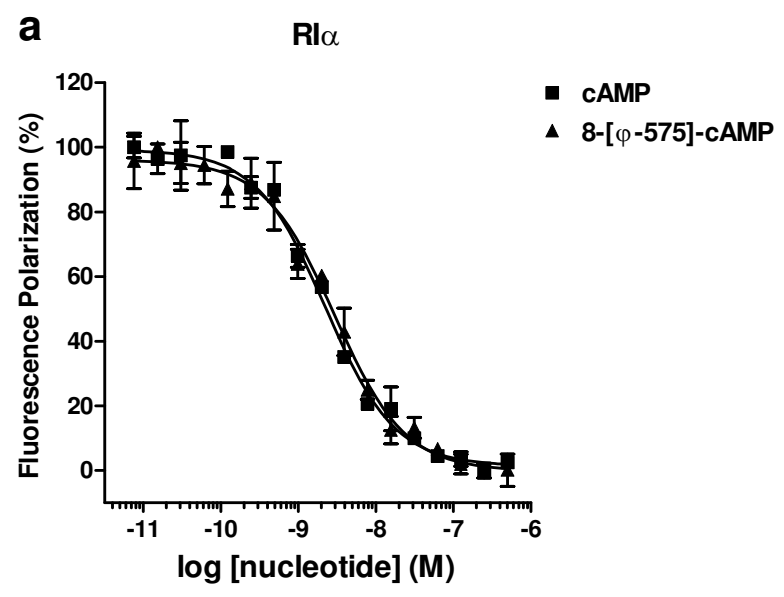

b

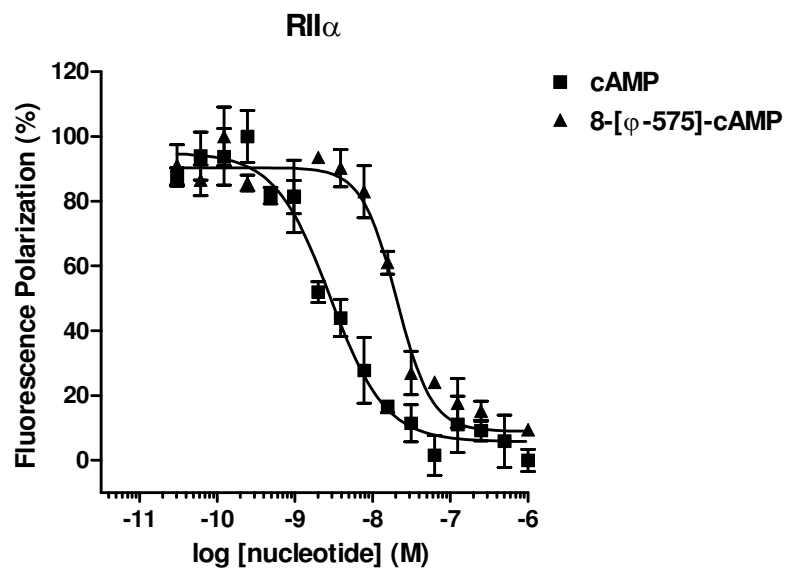

C

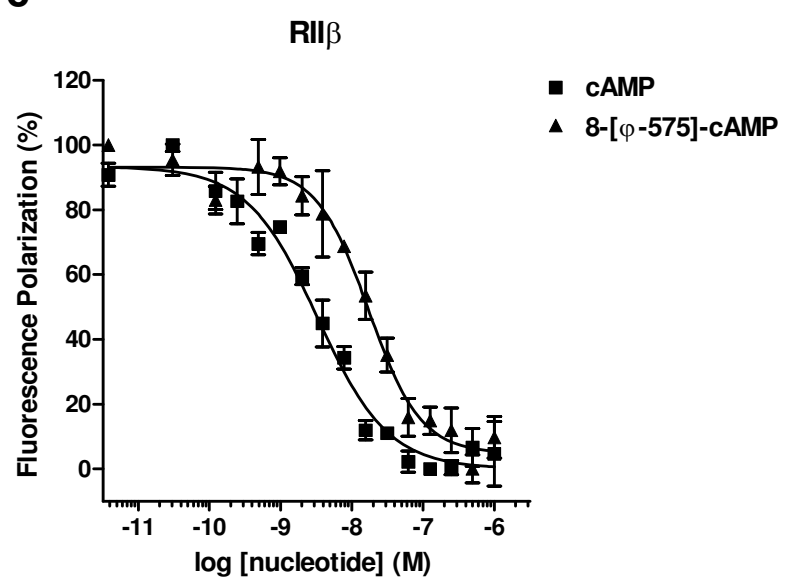

Figure 3

Competitive nucleotide binding assay using fluorescence polarization. Serial dilutions of cAMP or 8-[ $\varphi-575]-c A M P$ in the presence of I nM 8-Fluo-cAMP were prepared. $2.5 \mathrm{nM}$ R subunit was added and fluorescence polarization was determined

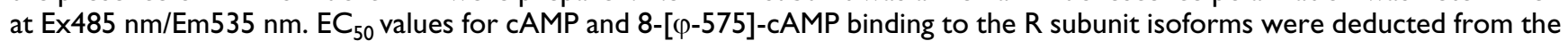
corresponding titration curves. Each data point represents the mean +/- S.E.M. from at least triplicate measurements. 


\section{a Rl $\alpha-H o l o e n z y m e$}

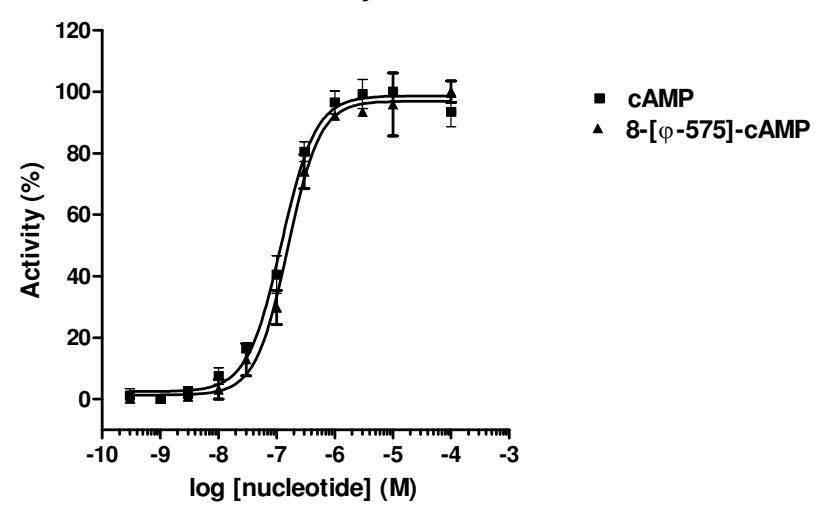

b Rll $\alpha$-Holoenzyme
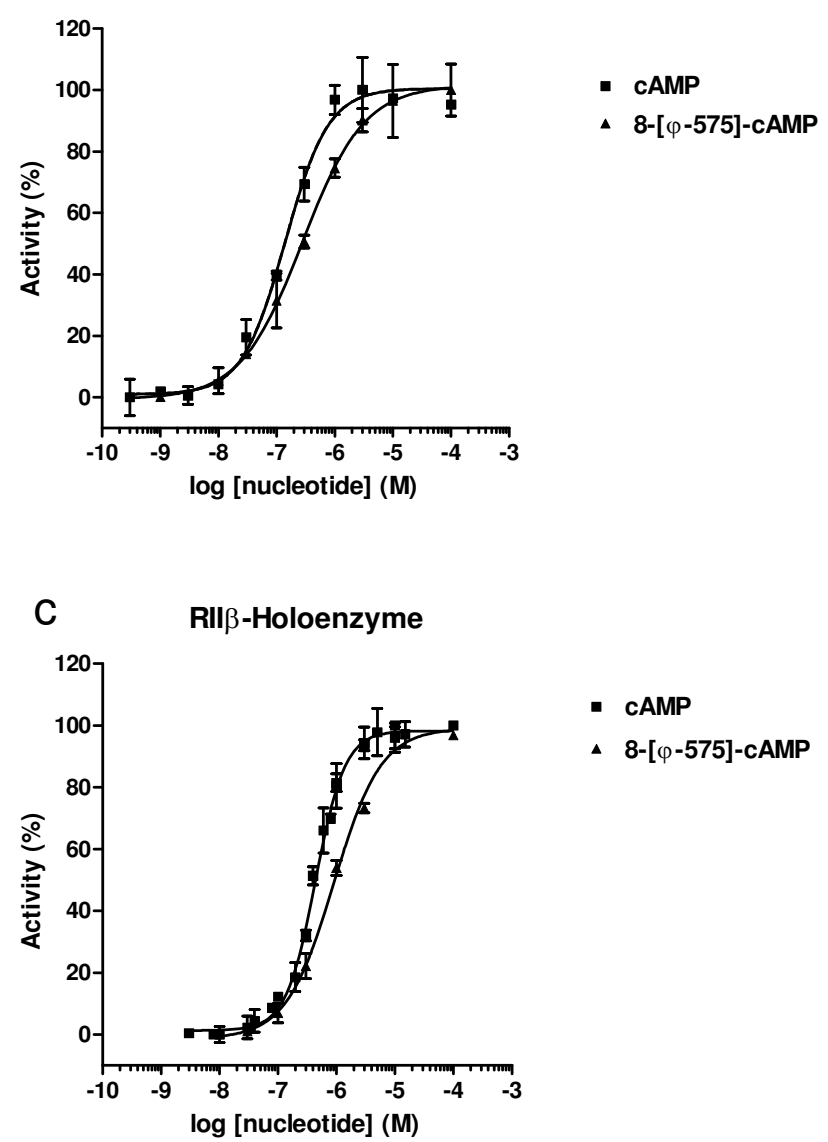

\section{Figure 4}

8-[ $\varphi$-575]-cAMP is a potent PKA activator in vitro. For determination of apparent activation constants, purified recombinant $R$ subunits were allowed to form holoenzyme complexes with PKA-C $\alpha(20 \mathrm{nM})$ as detailed in the methods section.

Activation assays were performed by increasing $(0.3 \mathrm{nM}-10 \mu \mathrm{M}) \mathrm{cAMP}$. To obtain apparent activation constants $\left(\mathrm{K}_{\mathrm{act}}\right)$, the normalized activity of PKA-C $\alpha$ was plotted against the logarithm of the CAMP ( ) and 8- $[\varphi-575]$-cAMP ( ) concentration and fitted according to a sigmoid dose-response model (Graphpad Prism, variable slope). Each data point represents the mean \pm S.D. of two measurements. Experiments were repeated two to three times with similar results. 

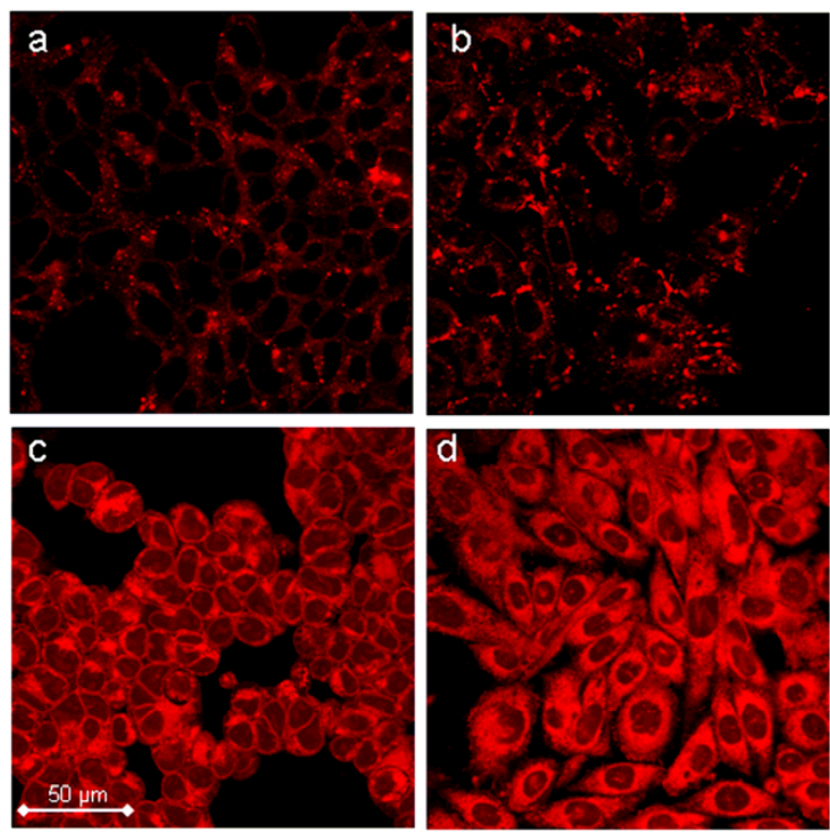

Figure 5

Visualization of compounds in living cells. Intracellular imaging of 8-[ $\varphi-575]-c A M P(a-b)$ and of Pharos dye (c-d) in HEK293 (a,c) and in CHO (b,d) cells after I hour of treatment.

which in turn is ligand-dependent, this probe is used to estimate the intracellular level of CAMP or -analogs.

The cells were treated with $500 \mu \mathrm{M} 8$ 8-[$\varphi$-575]-cAMP for one hour and, during this period, FRET ratio increased linearly (Fig. $7 \mathrm{a}-\mathrm{d}$ ). On the basis of the cAMP dose-FRET response curve [39], we estimate that about $7 \mu \mathrm{M} 8$-[ $\varphi$ 575]-cAMP is available to the intracellular fluorescent indicator. The same experiments were performed using Sp-5,6-DCl-cBIMPS, a highly membrane permeable cAMP analog [36]. In this case, after 40 minutes of treatment, the fluorescent probe was almost completely saturated (Fig. $7 \mathrm{e}-\mathrm{h})$, indicating that Sp-5,6-DCl-cBIMPS crosses the plasma membrane more efficiently compared to 8 - $[\varphi-$ 575]-cAMP, in contrast to the retention based lipophilicity measurements on HPLC, where the analogs behaved more similarly. We can not exclude, however, that the Epac- based FRET sensor used for the measurements preferentially binds Sp-5,6-DCl-cBIMPS.

As the reduced intracellular availability of $8-[\varphi-575]-$ cAMP could also be due to intracellular PDE-mediated degradation, we tested stability of the compound towards a cAMP-specific PDE isoform (PDE4D5) in vitro using a coupled spectrophotometric activity assay [40]. No degradation of $8-[\varphi-575]$-cAMP was detected during the 15 minutes of assay duration (data not shown). The specific activity of the enzyme was $0.6 \mathrm{U} / \mathrm{mg}$ for cAMP. It has been demonstrated before, that 8-modified cAMP analogs possess considerably high resistance towards PDE degradation [41]. Absolutely stable analogs would arise from conjugating the Pharos fluorophore to phosphorothioatemodified structures such as Rp- or Sp-cAMPS (Rp- or Spdiastereomer of adenosine 3'-5'-monophosphorothiorate).

We next tested if 8-[ $\varphi-575]$-cAMP can activate the PKA holoenzyme in living COS-7 cells using a recently established bioluminescence resonance energy transfer (BRET) based reporter for PKA-II $\alpha$, based on transient coexpressed luciferase-tagged RII $\alpha$ and (RII $\alpha$-RLuc) as the BRET donor and a GFP-tagged $\mathrm{C} \alpha$ subunit $\left(\mathrm{GFP}^{2}-\mathrm{C} \alpha\right)$ as the BRET acceptor. In this assay, a decrease in BRET signal indicates intracellular dissociation of the PKA holoenzyme [42]. As depicted in figure 8a, the cAMP analog efficiently allows the PKA subunits to dissociate. Halfmaximal holoenzyme dissociation was achieved at a concentration of about $600 \mu \mathrm{M}$ analog added to the cells. This value in the same range as the value for e.g. 8-Br-cAMP $\left(\mathrm{EC}_{50}=1.5 \mathrm{mM}[42]\right)$ but is surpassed by acetoxymethyl esters of cyclic nucleotides, that activate PKA in the low $\mu \mathrm{M}$ range determined by BRET [7] as well as in physiological assays [43]. Finally, we performed a bystander BRET test [44], where COS-7 cells were transfected with a constant amount of donor-expression plasmid (RII $\alpha$-RLuc, $0.5 \mu \mathrm{g}$ ) and with increasing amounts of acceptor-expression plasmid (GFP2-C $\alpha, 0-2 \mu \mathrm{g}$ ). The cells were incubated

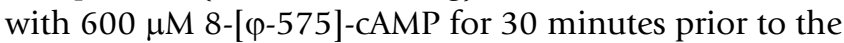
BRET ratio determination, or mock treated. Figure $8 \mathrm{~b}$ depicts the normalized BRET-values of two experiments each performed with $n=6$ wells per incubation. When no BRET acceptor is expressed in the cells, we observed the

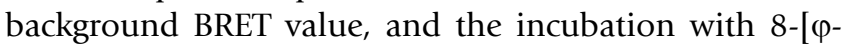
575]-cAMP has no effect. With increasing amounts of acceptor DNA, the BRET values rises and reaches an asymptote at the 1:1 molar ratio at $0.5 \mu \mathrm{g}$ donor and acceptor coding DNA each, as expected from a 1:1 interaction of PKA subunits in the holoenzyme. Thereafter the BRET value does not increase further, indicating a specific interaction, which can be prohibited to about $50 \%$ by incubation with $600 \mu \mathrm{M} 8$-[ $\varphi-575]$-cAMP, as determined previously (see figure $8 \mathrm{a}$ and $8 \mathrm{~b}$ ).

\section{Conclusion}

We can conclude that 8-[ $\varphi-575]$-cAMP with its modern, red-shifted fluorophore is a useful, stable tool for in vitro and in vivo investigation of cAMP binding proteins. It spontaneously enters eukaryotic cells and can be sequestered to PKA regulatory subunits. However, undesired partial accumulation in the cell could not be entirely excluded in this study. It efficiently binds to and activates 


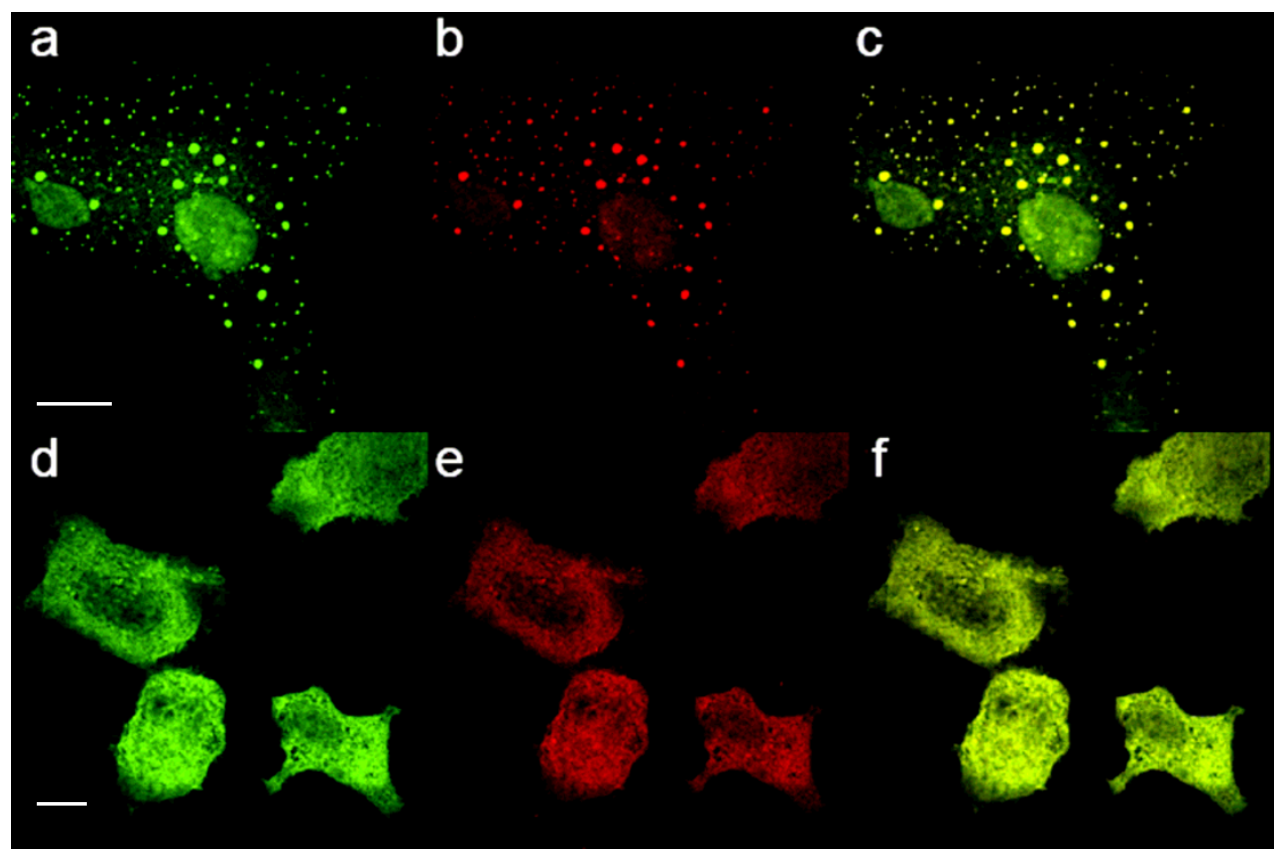

\section{Figure 6}

Co-localization of 8-[ $\varphi-575]$-cAMP and GFP-tagged $\mathbf{R}$ subunits. COS-7 cells were transiently transfected with GFP-

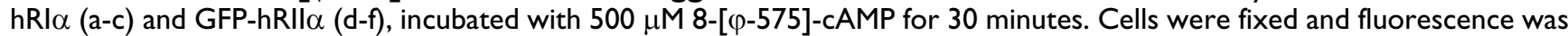
imaged using confocal microscopy: $(a, c)$ green fluorescence of GFP $(b, e)$, red fluorescence of 8-[ $\varphi-575]-c A M P,(c, f)$ merged images. The scale bar indicates $10 \mu \mathrm{m}$.

PKA-I and -II, and should have great potential for many cell biological and in vitro applications.

\section{Methods \\ Materials}

All cyclic nucleotides, as well as the free Pharos chromophore were derived from Biolog Life Science Institute (Bremen, Germany). The solubility of the novel Pharos compound is approximately $50 \mathrm{mM}$ in water. $\operatorname{LogK}_{\mathrm{w}}$ data were determined by a retention-based lipophilicity ranking using a LiChrograph HPLC (Merck-Hitachi, Darmstadt, Germany) equipped with a reversed phase YMC RP18 phase $(250 \times 4 \mathrm{~mm})$ running at a flow rate of $1.0 \mathrm{ml} /$ min. Nucleotides were detected at $\lambda=280 \mathrm{~nm}$ [35]. A. The purity of cyclic nucleotides was analyzed with an elution system consisting of $25 \%$ acetonitrile and $10 \mathrm{mM}$ triethyl ammonium formiate at a flow rate of $1.5 \mathrm{ml} / \mathrm{min}$ and was found to be $>99 \%$. No trace of free fluorophore was detected in $8-[\varphi-575]$-cAMP.

\section{Spectral measurements}

The Pharos dye was diluted in $20 \mathrm{mM}$ 2-(4-morpholino)ethane sulfonic acid (MES) buffer adjusted to $\mathrm{pH}$ 6.0, $\mathrm{pH}$ 7.0 and $\mathrm{pH} 7.4$, and all samples were degassed by bubbling nitrogen through the solution before measuring the absorption or fluorescence spectra.
For Stokes shift and quantum yield determination, absorption and fluorescence spectra were recorded in cells with $1 \mathrm{~cm}$ path length using a PerkinElmer Lambda 900 UV-Vis spectrophotometer and a Hitachi F-4500 fluorescence spectrophotometer, respectively.

To calculate the relative quantum yield $\varphi$ of the free Pharos dye, the absorption ( $500 \mathrm{~nm}$ to $640 \mathrm{~nm}$ ) and fluorescence $\left(\lambda_{\text {ex }}=553 \mathrm{~nm}, \lambda_{\text {em }}\right.$ ranging from $558 \mathrm{~nm}$ to $800 \mathrm{~nm}$ ) spectra of several Pharos dye concentrations ( $640 \mathrm{nM}$ to $64.2 \mu \mathrm{M}$ ) were recorded in A. bidest. The integrated fluorescence intensity (I) was plotted versus the absorbance (A) at the excitation wavelength. For low concentrations the dye molecules are not influenced by each other and thus exhibit a linear behavior concerning absorption and emission of light. Linear regression yields the slope $\Delta \mathrm{I} / \Delta \mathrm{A}$ that is compared to the corresponding data of a quantum yield standard by using the equation $\varphi_{\mathrm{sa}}=\left(\Delta \mathrm{I}_{\mathrm{sa}}\right)$ $\left.\Delta \mathrm{A}_{\mathrm{sa}}\right) \cdot\left(\Delta \mathrm{A}_{\mathrm{st}} / \Delta \mathrm{I}_{\mathrm{st}}\right) \cdot \varphi_{\mathrm{st}}$. As a standard, a solution of quinine sulfate in $1.0 \mathrm{~N}$ sulfuric acid $\left(\varphi_{\mathrm{st}}=0.546\right.$ with $\lambda_{\text {ex }}=365$ $\mathrm{nm})$ was used $[21,22]$.

For emission and excitation spectra (Kontron SFM25) with and without purified regulatory subunit of PKA (see below), $100 \mathrm{nM} 8$-[ $\varphi$-575]-cAMP was measured with and without fourfold molar excess of regulatory subunit in 20 


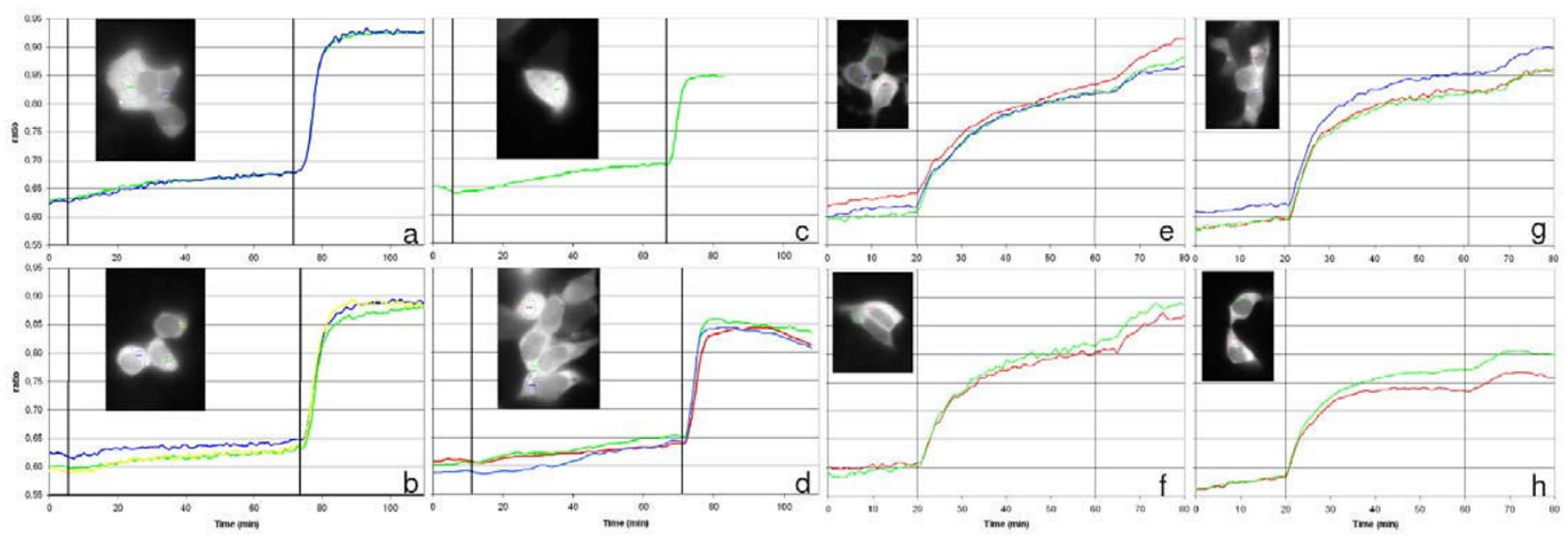

Figure 7

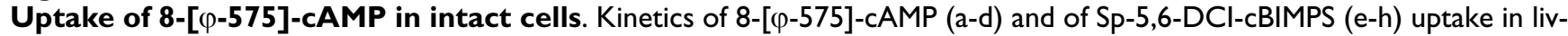
ing cells. HEK293 cells were transfected for transient expression of the H30 indicator of cAMP and treated with I00 $\mu$ M IBMX to inhibit phosphodiesterases. The ratio between the background subtracted emission intensities at $480 \mathrm{~nm}$ and $545 \mathrm{~nm}$ is plotted as a function of time. The vertical bars indicate the administrations of either $500 \mu \mathrm{M} 8-[\varphi-575]-c A M P(a-d)$ or Sp-5,6-DClcBIMPS (e-h) and of $25 \mu \mathrm{M}$ Forskolin, which activates adenylyl cyclase and saturates the FRET-based probe. The insets show the yellow fluorescent protein fluorescence at the beginning of the experiments and the regions of interest where FRET ratios are calculated.

a

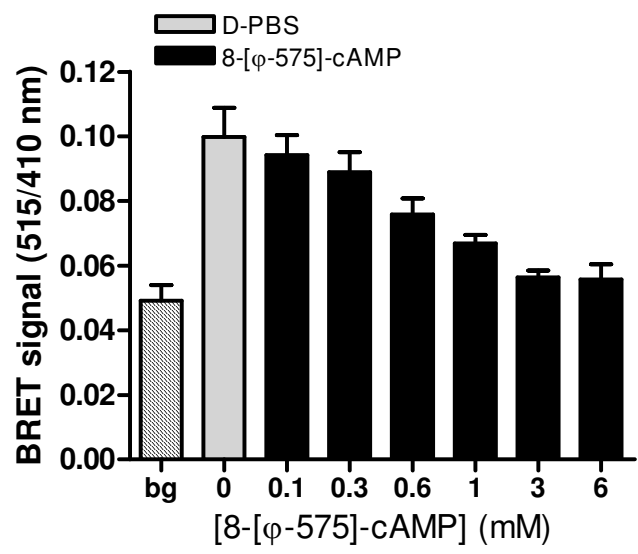

b

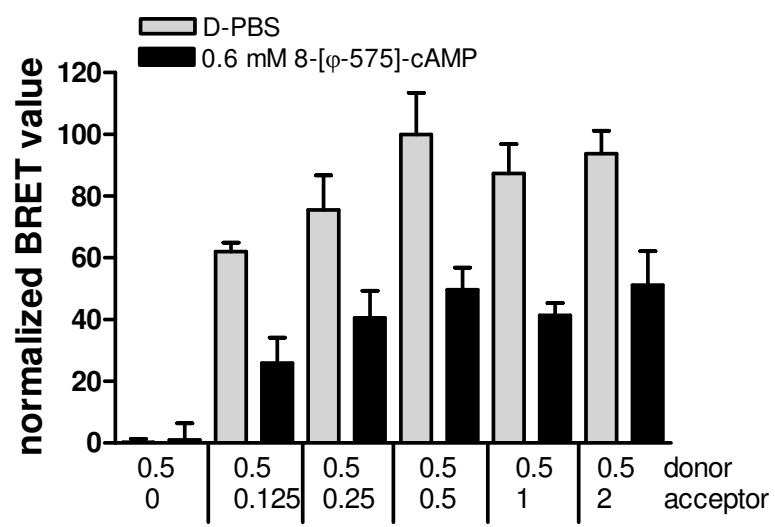

\section{Figure 8}

8-[ $\varphi$-575]-cAMP activates intracellular PKA. (a) For standard BRET experiments, COS-7-cells were co-transfected with the PKA type II sensor construct or negative control plasmids (bg) as indicated and grown for 48 hours. Cells were treated

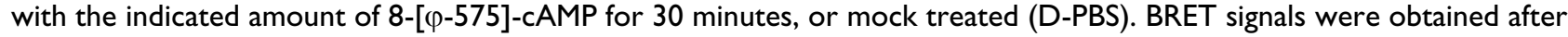
addition of the luciferase substrate DeepBlue ${ }^{\mathrm{TM}}$ and detection of luciferase and fluorescence light emission using a multi-label reader. Shown is a representative experiment, repeated three times; data are mean \pm S.E.M., performed with $\mathrm{n}=6$ replicates. (b) A BRET titration experiment was performed as described in the methods section. Briefly, cells were co-transfected with a constant amount of BRET donor (hRIl $\alpha$-Rluc) and an increasing amount of acceptor DNA (GFP2-hC $\alpha$ ) as indicated. Before BRET read-out, cells were incubated with $0.6 \mathrm{mM}$ 8-[$[\varphi-575]-c A M P$ as described above. The BRET values of two independent experiments, each performed with $n=6$ replicates, were background subtracted, normalized and plotted as mean \pm S.E.M. 
mM MOPS, $150 \mathrm{mM} \mathrm{NaCl}, 1 \mathrm{mM} \beta$-mercaptoethanol, $\mathrm{pH}$ (buffer A) at room temperature. The excitation spectra were detected at $\lambda_{\mathrm{em}}=617 \mathrm{~nm}$ with $\lambda_{\mathrm{ex}}$ ranging from 610 $\mathrm{nm}$ to $430 \mathrm{~nm}$; emission spectra were measured with $\lambda_{\mathrm{ex}}=$ $575 \mathrm{~nm}$ with $\lambda_{\mathrm{em}}$ ranging from $800 \mathrm{~nm}$ to $580 \mathrm{~nm}$.

\section{Expression and purification of PKA subunits}

For expression of PKA regulatory subunits, one liter of Luria Broth medium containing $100 \mu \mathrm{g} / \mathrm{ml}$ of ampicillin was inoculated with E. coli BL21 (DE3) Codon Plus RIL cells (Stratagene) transformed with human RI $\alpha$, RI $\beta$, RII $\alpha$ (in pRSET ${ }_{\mathrm{B}}$ ) or rat RII $\beta$ (in pETIIc) and grown at $37^{\circ} \mathrm{C}$ to an $\mathrm{OD}_{600} \mathrm{~nm}$ of 0.8 . Recombinant protein expression was induced by addition of $0.2 \mathrm{M}$ isopropyl- $\beta$-D-thiogalactopyranoside (IPTG) and the culture was incubated at $25^{\circ} \mathrm{C}$ for additional $17-18 \mathrm{~h}$. The pellets were stored at $-20^{\circ} \mathrm{C}$.

For purification of RI isoforms (Moll et al., submitted), cell lysis of protein expressing E. coli cells was performed two times with a French Pressure Cell (Thermo Electron Corp., Needham Heights, USA) in lysis buffer (20 mM 3(N-morpholino) propane sulfonic acid (MOPS), $100 \mathrm{mM}$ $\mathrm{NaCl}, 1 \mathrm{mM} \beta$-mercaptoethanol, $2 \mathrm{mM}$ EDTA, $2 \mathrm{mM}$ EGTA, pH7.0). The lysate was centrifuged at $27000 \times \mathrm{g}$ for $30 \mathrm{~min}$ and $4^{\circ} \mathrm{C}$. $1.2 \mu \mathrm{mol}$ Sp-8-AEA-cAMPS-agarose (Biolog Life Science Inst.) was used per purification, corresponding to 300-450 $\mu \mathrm{l}$ agarose-slurry. The protein content in $12 \mathrm{ml}$ clarified supernatant was batch bound by gentle rotation over night by $4^{\circ} \mathrm{C}$. The agarose was washed seven times with $1.25 \mathrm{ml}$ lysis buffer. The protein elution step was performed with $1.25 \mathrm{ml}$ of $10 \mathrm{mM}$ cGMP in buffer A by gentle rotation at $4^{\circ} \mathrm{C}$ for $1 \mathrm{~h}$. The agarose was rinsed with two additional wash steps (each $825 \mu \mathrm{l}$ ) with buffer A. Subsequently, the R subunits were subjected to gel filtration (PD10, Amersham Pharmacia Biotech, Freiburg, Germany) into buffer A. To remove all cGMP, the $\mathrm{R}$ subunits were dialyzed excessively against buffer A.

For purification of RII isoforms (Moll et al., submitted), cell lysis was performed in buffer consisting $20 \mathrm{mM}$ MES, pH6.5, $100 \mathrm{mM} \mathrm{NaCl}, 5 \mathrm{mM}$ EDTA, $5 \mathrm{mM}$ EGTA and 5 $\mathrm{mM} \beta$-mercaptoethanol with added protease inhibitors (PI): Leupeptin (0.025 mg/100 ml), TPCK and TLCK (each $1 \mathrm{mg} / 100 \mathrm{ml}$ ) (buffer B). after centrifugation at 27 $000 \times \mathrm{g}$ for $30 \mathrm{~min}$ and $4^{\circ} \mathrm{C}$, the supernatant was precipitated at $4{ }^{\circ} \mathrm{C}$ with $50 \%$ saturated ammonium sulfate (AS) for RII $\alpha$ and $45 \%$ AS for RII $\beta$ and centrifuged by 10000 $\times \mathrm{g}, 15 \mathrm{~min} 4^{\circ} \mathrm{C}$. The AS pellets were re-suspended in buffer B and protein was batch bound to $1.4 \mu \mathrm{mol}$ settled Sp-8-AEA-cAMPS-agarose. The agarose was rinsed twice with $20 \mathrm{mM}$ MOPS, pH7.0, $1 \mathrm{M} \mathrm{NaCl}, 5 \mathrm{mM} \beta$-mercaptoethanol and then two times with $10 \mathrm{ml}$ buffer B. Subsequently, two elution steps were carried out with $25 \mathrm{mM}$ cGMP in buffer B. RII subunits were subjected to gel filtra- tion into $20 \mathrm{mM}$ MES, pH 6.5,150 mM NaCl, $2 \mathrm{mM}$ EDTA, 2 mM EGTA, $1 \mathrm{mM} \beta$-mercaptoethanol.

Murine $\mathrm{C} \alpha$ subunit (in $\mathrm{pRSET}_{\mathrm{B}}$ ) was expressed in E. coli BL21 (DE3) (Stratagene) and purified as published previously $[45,46]$. Protein expression and purification was followed by SDS-polyacrylamid gel electrophoresis [47]. Typically, the recombinant proteins were purified to $95 \%$ homogeneity or higher.

\section{Fluorescence Polarization (FP)}

The fluorescence polarization displacement assay was performed as described before[7]. Increasing concentrations of CAMP or 8-[ $\varphi-575]$-cAMP were mixed with $1 \mathrm{nM} 8$ Fluo-cAMP before adding $2.5 \mathrm{nM}$ regulatory subunit RI $\alpha$, RII $\alpha$, RII $\beta$. Fluorescence polarization was measured after 5 minutes of incubation at room temperature.

\section{Determination of activation constants}

PKA activity was assayed by the coupled spectrophotometric assay first described by Cook et al. [26] using 260 $\mu \mathrm{M}$ Kemptide (LRRASLG) as the substrate. Holoenzyme formation was carried out for 3 minutes at room temperature with $20 \mathrm{nM}$ murine PKA-C $\alpha$ subunit and an about 1.2 fold molar excess cAMP-free RI $\alpha$, RII $\alpha$, or RII $\beta$ subunit in assay mixture $\left(10 \mathrm{mM} \mathrm{MgCl}_{2}, 100 \mu \mathrm{M} \mathrm{ATP}, 100 \mathrm{mM}\right.$ MOPS, $1 \mathrm{mM}$ PEP, LDH, pyruvate kinase, NADH, $5 \mathrm{mM}$ $\beta$-mercaptoethanol, $\mathrm{pH}$ 7.0). Apparent activation constants $\left(\mathrm{K}_{\mathrm{act}}, \mathrm{EC}_{50}\right)$ were determined by adding increasing amounts of cAMP or 8-[ $\varphi-575]$-cAMP $(0.3 \mathrm{nM}$ to $10 \mu \mathrm{M})$.

\section{BRET assay}

COS-7 cells were used for BRET experiments. They were routinely passaged and seeded in opaque 96-well microplates (CulturPlate ${ }^{\mathrm{TM}}-96$, PerkinElmer) 24 hours prior to co-transfection with the previously described PKA-II $\alpha$ sensor, comprised of RII $\alpha$-RLuc (donor) and GFP2-C $\alpha$ (acceptor) [42]. Two days following transfection with 0.5 $\mu \mathrm{g}$ donor and acceptor DNA, respectively, cells were rinsed with glucose-supplemented Dulbecco's PBS (DPBS, Invitrogen), and subsequently incubated with $8-[\varphi$ 575]-cAMP (0.01-6 mM final concentration in D-PBS, prepared from a $20 \mathrm{mM}$ stock solution), or mock treated for 30 minutes at room temperature. For the BRET readout, the luciferase substrate DeepBlueC ${ }^{\text {тм }}$ (PerkinElmer) was added at a final concentration of $5 \mu \mathrm{M}$ in a total volume of $50 \mu \mathrm{l}$ D-PBS. Light output was detected consecutively using a Fusion $^{\mathrm{TM}} \alpha$-FP microplate reader (PerkinElmer, read time 1s, gain 25) equipped with appropriate filters for the donor (RLuc; $\lambda=410 \mathrm{~nm} \pm 80$ $\mathrm{nm}$ ) and for the acceptor fluorophore (GFP $2 ; \lambda=515 \mathrm{~nm}$ $\pm 30 \mathrm{~nm}$ ) emission. Emission values obtained with untransfected (n.t.) cells were routinely subtracted, and BRET signals were calculated as follows: (emission $_{(515 \mathrm{~nm})}$ - n.t. cells $\left._{(515 \mathrm{~nm})}\right) /\left(\operatorname{emission}_{(410 \mathrm{~nm})}-\right.$ n.t. cells $\left.(410 \mathrm{~nm})\right)$. 
Control measurements with cells expressing RLuc and GFP proteins without a fusion partner yield the background BRET signal. A BRET titration (bystander BRET test) was performed by co-transfection of COS-7 cells with a constant donor-expression plasmid $(0.5 \mu \mathrm{g})$ with an increasing amount of acceptor-expression plasmid (0-2 $\mu \mathrm{g})$. The cells were treated as described above. Prior to the BRET read-out, cells were incubated with or without 0.6

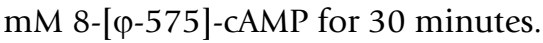

\section{Uptake of 8-[ $\varphi-575]-c A M P$ in living cells}

HEK293 and CHO cells were grown in the Dulbecco's modified Eagle medium (DMEM, Invitrogen) and F12 nutrient mixture (HAM, Invitrogen) mediums, respectively, containing 10\% FBS and supplemented with $2 \mathrm{mM}$ L-glutamine, $100 \mathrm{U} / \mathrm{ml}$ penicillin, and $100 \mu \mathrm{g} / \mathrm{ml}$ streptomycin (all: Sigma-Aldrich), in a $37^{\circ} \mathrm{C}$ humidified atmosphere containing $5 \% \mathrm{CO}_{2}$. These cell lines are routinely used in our laboratory for FRET experiments using various sensors and they have been thoroughly characterized for fluorescent sensor expression levels.

For transient expression of the H30 sensor, cells were seeded onto 24-mm diameter round glass coverslips, and transfections were performed at 50-70\% confluence with FuGENE-6 transfection reagent (Roche). Imaging experiments were performed after about $24 \mathrm{~h}$. Cells were maintained in Hepes-buffered Ringer-modified solution, containing $125 \mathrm{mM} \mathrm{NaCl}, 5 \mathrm{mM} \mathrm{KCl}, 1 \mathrm{mM} \mathrm{Na}_{3} \mathrm{PO}_{4}, 1$ $\mathrm{mM} \mathrm{MgSO}_{4}, 5.5 \mathrm{mM}$ glucose, $1 \mathrm{mM} \mathrm{CaCl}_{2}$, and $20 \mathrm{mM}$ Hepes, $\mathrm{pH} 7.4$, at room temperature and treated with 100 $\mu \mathrm{M}$ 3-Isobutyl-1-methylxanthine (IBMX, Sigma-Aldrich) 10 minutes before the experiments. Cells were imaged on an inverted microscope (IX50; Olympus) with a 60× oil immersion objective (Olympus). The microscope was equipped with a monochromator (Polychrome IV; TILL Photonics) and a beam-splitter optical device (Multispec Microimager; Optical Insights). FRET variations were measured as changes of the ratio between the background-subtracted fluorescence emission intensities at $480 \mathrm{~nm}$ and $545 \mathrm{~nm}$, on excitation at $430 \mathrm{~nm}$. Forskolin (25 $\mu \mathrm{M}$, Sigma-Aldrich) was added to saturate the FRET probe and to determine the maximal FRET response.

For the imaging of the intracellular distribution of $8-[\varphi$ 575]-cAMP and the Pharos dye, cells were grown and seeded as above. Before the image acquisitions, cells were treated with $100 \mu \mathrm{M}$ IBMX and either $500 \mu \mathrm{M} 8-[\varphi-575]-$ CAMP or the Pharos dye for 1 hour. Cells were then washed with the Hepes-buffered Ringer-modified solution described above and imaged on a confocal microscope (Leica) with a $20 \times$ oil immersion objective (Leica). Images were obtained by collecting the emission light from $600 \mathrm{~nm}$ to $640 \mathrm{~nm}$, on excitation at $514 \mathrm{~nm}$.
Intracellular co-localization of 8-[ $\varphi$-575]-cAMP and GFPhRI $\alpha$ or GFP-hRII $\alpha$ was examined in COS-7 cells after two days transient expression of the GFP-tagged $\mathrm{R}$ subunits [42]. Cloning of the R subunits into the expression vector hpGFP' ${ }^{2}-\mathrm{N}_{2}$ (PerkinElmer) was performed as described previously [48]. The cells were incubated for 30 minutes at $37^{\circ} \mathrm{C}$ with $500 \mu \mathrm{M}$ 8-[ $\varphi$-575]-CAMP in D-PBS, rinsed tree times with D-PBS, followed by a standard fixation procedure [42]. Cellular imaging was performed on a confocal microscope (Leica) with a Plan apo $100 \times$ oil immersion objective (Leica).

\section{Statistical procedures}

Measurement and statistical evaluation of FP, kinase activity and BRET assays was carried out using GraphPad Prism software version 4 (GraphPad Software).

\section{Abbreviations}

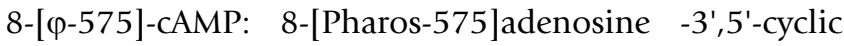
monophosphate; 8-Fluo-cAMP: 8-[2-[(Fluoresceinylthioureido)aminolethyl] thio]adenosine -3 ',5'-cyclic monophosphate; Sp-5,6-DCl-cBIMPS: 5,6dichlorobenzimidazole riboside -3',5'-cyclic monophosphorothioate, Sp-isomer; 8-pCPT-2'-O-Me-cAMP: 8-(4chlorophenylthio)-2'-O-methyladenosine $\quad-3$ ',5'-cyclic monophosphate; 8-Br-cAMP: 8-Bromoadenosine -3',5'cyclic monophosphate; Sp-8-AEA-cAMPS-agarose: 8-(2aminoethylamino)adenosine -3',5'-cyclic monophosphorothioate, Sp- isomer, immobilized to agarose; MOPS: 3(N-morpholino) propane sulfonic acid; MES: 2-(4-morpholino)-ethane sulfonic acid; PKA: protein kinase A, cAMP-dependent protein kinase; R: regulatory subunit; $\mathrm{C}$ : catalytic subunit; FRET: Fluorescence resonance energy transfer; BRET: bioluminescence resonance energy transfer; PDE: phosphodiesterase; IBMX: 3-Isobutyl-1-Methylxanthine.

\section{Authors' contributions}

H-GG synthesized the Pharos compounds and performed studies on stability and lipophilicity, DM and CMB performed the physical characterization experiments, DM performed the FP assay, AP coordinated the study, performed BRET and kinase activity assays, cellular distribution evaluation and co-localization experiments; $\mathbf{M B}$ performed FRET assays and cellular distribution evaluation, KG performed cellular co-localization experiments and the PDE assay, FWH and $\mathrm{MZ}$ contributed to the design of the experiments in this study and the data evaluation, AP and H-GG wrote the manuscript. 


\section{Additional material}

\section{Additional File 1}

An additional PDF-document (Moll_Prinz_et al_Additional file) illustrating the quantum yield determination of the Pharos dye is provided. Click here for file

[http://www.biomedcentral.com/content/supplementary/14712091-9-18-S1.pdf]

\section{Acknowledgements}

We thank M. Diskar, C. Demme, M. Hantsch and H.-M. Zenn for technical assistance. H. Rühling (University of Kassel) is acknowledged for confocal microscopy imaging. Plasmids for expression of $h R l \alpha, h R I l \alpha r R I I \beta$ and $m C \alpha$ were a kind gift of Prof. Dr. S.S. Taylor, UC San Diego, U.S.A. Recombinant PDE4D5 enzyme was kindly provided by Prof. Dr. M.D. Houslay, University of Glasgow, Scotland. This project was supported by grants of the EU (LSHB-CT-2006-037I89) to FWH, MZ, and HG, BMBF NGFN2 (FKZ0IGR044I) and DFG (He I8I8/4) to FWH, CMB is supported by a Ph.D. grant of the University of Kassel.

\section{References}

I. Cremo CR: Fluorescent nucleotides: synthesis and characterization. Methods Enzymol 2003, 360:128-177.

2. Builder SE, Beavo JA, Krebs EG: Stoichiometry of CAMP and I,N6-etheno-cAMP binding to protein kinase. J Biol Chem 1980, 255(6):2350-2354.

3. Tsou KC, Yip KF, Lo KW: I,N6-etheno-2-aza-adenosine 3',5'monophosphate: a new fluorescent substrate for cycle nucleotide phosphodiesterase. Anal Biochem I974, 60(I): I63-I69.

4. Scott SP, Tanaka JC: Molecular interactions of 3',5'-cyclic purine analogues with the binding site of retinal rod ion channels. Biochemistry 1995, 34(7):2338-2347.

5. Alfonso A, Estevez M, Louzao MC, Vieytes MR, Botana LM: Determination of phosphodiesterase activity in rat mast cells using the fluorescent cAMP analogue anthraniloyl cAMP. Cell Signal 1995, 7(5):513-518.

6. Hiratsuka T: New fluorescent analogs of CAMP and cGMP available as substrates for cyclic nucleotide phosphodiesterase. J Biol Chem 1982, 257(22): I 3354-13358.

7. Moll D, Prinz A, Gesellchen F, Drewianka S, Zimmermann B, Herberg FW: Biomolecular interaction analysis in functional proteomics. I Neural Transm 2006, I I3(8): I015-1032.

8. Kraemer A, Rehmann HR, Cool RH, Theiss C, de Rooij J, Bos JL, Wittinghofer A: Dynamic interaction of CAMP with the Rap guanine-nucleotide exchange factor Epacl. J Mol Biol 200I, 306(5): I I67-II77.

9. Mucignat-Caretta $C$, Caretta A: Binding of two fluorescent cAMP analogues to type I and II regulatory subunits of CAMP dependent protein kinases. Biochim Biophys Acta 1997 I 357(I):81-90.

10. Sako Y, Hibino K, Miyauchi T, Miyamoto Y, Ueda M, Yanagida T: Single-molecule imaging of signaling molecules in living cells. Single Mol 2000, I:|5|-|55.

II. Johnson ID, Kang HC, Haugland RP: Fluorescent membrane probes incorporating dipyrrometheneboron difluoride fluorophores. Anal Biochem I99I, I 98(2):228-237.

12. Haugland RP: Handbook of Fluorescent Probes and Research Products. 9th edition. Edited by: Probes GJM. Eugene, OR ; 2002.

13. Okada CY, Rechsteiner M: Introduction of macromolecules into cultured mammalian cells by osmotic lysis of pinocytic vesicles. Cell I 982, 29(I):33-4I.

14. Hagen V, Bendig J, Frings S, Eckardt T, Helm S, Reuter D, Kaupp UB: Highly Efficient and Ultrafast Phototriggers for CAMP and cGMP by Using Long-Wavelength UV/Vis-Activation. Angew Chem Int Ed Engl 200I, 40(6): I045-1048.
I5. Furuta T, Takeuchi H, Isozaki M, Takahashi Y, Kanehara M, Sugimoto M, Watanabe T, Noguchi K, Dore TM, Kurahashi T, Iwamura M, Tsien RY: Bhc-cNMPs as either water-soluble or membrane-permeant photoreleasable cyclic nucleotides for both one- and two-photon excitation. Chembiochem 2004, 5(8): I I I 9- I I 28.

16. Tasken K, Skalhegg BS, Tasken KA, Solberg R, Knutsen HK, Levy FO, Sandberg M, Orstavik S, Larsen T, Johansen AK, Vang T, Schrader HP, Reinton NT, Torgersen KM, Hansson V, Jahnsen T: Structure, function, and regulation of human CAMP-dependent protein kinases. Adv Second Messenger Phosphoprotein Res 1997, 3 I: I 9 |-204.

17. Gonzalez GA, Montminy MR: Cyclic AMP stimulates somatostatin gene transcription by phosphorylation of CREB at serine 133. Cell 1989, 59(4):675-680.

18. Skalhegg BS, Tasken K: Specificity in the CAMP/PKA signaling pathway. differential expression, regulation, and subcellular localization of subunits of PKA. Front Biosci 1997, 2:d33 I-42.

19. Craven KB, Zagotta WN: CNG and HCN channels: two peas, one pod. Annu Rev Physiol 2006, 68:375-40I.

20. de Rooij J, Rehmann H, van Triest M, Cool RH, Wittinghofer A, Bos JL: Mechanism of regulation of the Epac family of CAMP. dependent RapGEFs. J Biol Chem 2000, 275(27):20829-20836.

21. Crosby GA, Demas JN: Measurement of photoluminescence quantum yields. J Phys Chem 1971, 75(8):991-1024.

22. Melhuish WH: Quantum efficiencies of fluorescence of organic substances: effect of solvent and concentration of the fluorescent solute. J Phys Chem 196I, 65(2):229 -2235.

23. Schwede F, Christensen A, Liauw S, Hippe T, Kopperud R, Jastorff B, Doskeland SO: 8-Substituted cAMP analogues reveal marked differences in adaptability, hydrogen bonding, and charge accommodation between homologous binding sites (AI/AII and BI/BII) in CAMP kinase I and II. Biochemistry 2000, 39(30):8803-88I2.

24. Ogreid D, Ekanger R, Suva RH, Miller JP, Sturm P, Corbin JD, Doskeland SO: Activation of protein kinase isozymes by cyclic nucleotide analogs used singly or in combination. Principles for optimizing the isozyme specificity of analog combinations. Eur J Biochem 1985, I 50(I):219-227.

25. Ogreid D, Ekanger R, Suva RH, Miller JP, Doskeland SO: Comparison of the two classes of binding sites ( $A$ and $B$ ) of type $I$ and type II cyclic-AMP-dependent protein kinases by using cyclic nucleotide analogs. Eur J Biochem 1989, I 8 I(I): |9-3I.

26. Cook PF, Neville ME Jr., Vrana KE, Hartl FT, Roskoski R Jr.: Adenosine cyclic 3',5'-monophosphate dependent protein kinase: kinetic mechanism for the bovine skeletal muscle catalytic subunit. Biochemistry 1982, 2 I (23):5794-5799.

27. Dostmann WR, Taylor SS: Identifying the molecular switches that determine whether (Rp)-cAMPS functions as an antagonist or an agonist in the activation of CAMP-dependent protein kinase I. Biochemistry I99I, 30(35):8710-87I6.

28. Herberg FW, Taylor SS, Dostmann WR: Active site mutations define the pathway for the cooperative activation of CAMP. dependent protein kinase. Biochemistry 1996, 35(9):2934-2942.

29. Malgaroli A, Milani D, Meldolesi J, Pozzan T: Fura-2 measurement of cytosolic free $\mathrm{Ca2+}$ in monolayers and suspensions of various types of animal cells. J Cell Biol 1987, I 05(5):2 I 45-2I 55.

30. Poenie M, Alderton J, Steinhardt R, Tsien R: Calcium rises abruptly and briefly throughout the cell at the onset of anaphase. Science 1986, 233(4766):886-889.

31. Szaszak M, Christian F, Rosenthal W, Klussmann E: Compartmentalized CAMP signalling in regulated exocytic processes in non-neuronal cells. Cell Signal 2007.

32. Mucignat-Caretta C, Caretta A: Localization of Triton-insoluble cAMP-dependent kinase type RIbeta in rat and mouse brain. J Neurocytol 200I, 30( I I):885-894.

33. Mucignat-Caretta C, Caretta A: Clustered distribution of CAMP. dependent protein kinase regulatory isoform $R I$ alpha during the development of the rat brain. J Comp Neurol 2002, 45 I (4):324-333.

34. Mucignat-Caretta C, Caretta A: Distribution of insoluble cAMP. dependent kinase type RI and RII in the lizard and turtle central nervous system. Brain Res 2007.

35. Kraß J, Jastorff B, Genieser HG: Determination of Lipophilicity by Gradient Elution High-Performance Liquid Chromatography. Anal Chem 1997, 69:2575 -2258I.

36. Sandberg M, Butt E, Nolte C, Fischer L, Halbrugge M, Beltman J, Jahnsen T, Genieser HG, Jastorff B, Walter U: Characterization of 
Sp-5,6-dichloro-I-beta-D-ribofuranosylbenzimidazole- 3',5'monophosphorothioate (Sp-5,6-DCl-cBiMPS) as a potent and specific activator of cyclic-AMP-dependent protein kinase in cell extracts and intact cells. Biochem J I 99|, 279 ( Pt 2):52I-527.

37. Enserink JM, Christensen AE, de Rooij J, van Triest M, Schwede F, Genieser HG, Doskeland SO, Blank JL, Bos JL: A novel Epac-specific CAMP analogue demonstrates independent regulation of Rap I and ERK. Nat Cell Biol 2002, 4(I I):90I-906.

38. Ponsioen B, Zhao J, Riedl J, Zwartkruis F, van der Krogt G, Zaccolo M, Moolenaar WH, Bos JL, Jalink K: Detecting cAMP-induced Epac activation by fluorescence resonance energy transfer: Epac as a novel cAMP indicator. EMBO Rep 2004, 5(I2): $1176-1 \mid 80$.

39. Terrin A, Di Benedetto G, Pertegato V, Cheung YF, Baillie G, Lynch MJ, Elvassore N, Prinz A, Herberg FW, Houslay MD, Zaccolo M: PGE(I) stimulation of HEK293 cells generates multiple contiguous domains with different [CAMP]: role of compartmentalized phosphodiesterases. I Cell Biol 2006, 175(3):44|-45I.

40. Chock SP, Huang CY: An optimized continuous assay for CAMP phosphodiesterase and calmodulin. Anal Biochem 1984 I 38(I):34-43.

4I. Schwede F, Maronde E, Genieser H, Jastorff B: Cyclic nucleotide analogs as biochemical tools and prospective drugs. Pharmacol Ther 2000, 87(2-3): 199-226.

42. Prinz A, Diskar M, Erlbruch A, Herberg FW: Novel, isotype-specific sensors for protein kinase $A$ subunit interaction based on bioluminescence resonance energy transfer (BRET). Cell Signal 2006, 18(10): 1616-1625.

43. Schultz C, Vajanaphanich M, Harootunian AT, Sammak PJ, Barrett KE, Tsien RY: Acetoxymethyl esters of phosphates, enhancement of the permeability and potency of cAMP. J Biol Chem 1993, 268(9):6316-6322.

44. Marullo $S$, Bouvier M: Resonance energy transfer approaches in molecular pharmacology and beyond. Trends Pharmacol Sci 2007, 28(8):362-365.

45. Slice LW, Taylor SS: Expression of the catalytic subunit of cAMP-dependent protein kinase in Escherichia coli. I Biol Chem 1989, 264(35):20940-20946.

46. Herberg FW, Bell SM, Taylor SS: Expression of the catalytic subunit of CAMP-dependent protein kinase in Escherichia coli: multiple isozymes reflect different phosphorylation states. Protein Eng 1993, 6(7):771-777.

47. Laemmli UK: Cleavage of structural proteins during the assembly of the head of bacteriophage T4. Nature 1970, 227(5259):680-685.

48. Prinz A, Diskar M, Herberg FW: Application of bioluminescence resonance energy transfer (BRET) for biomolecular interaction studies. Chembiochem 2006, 7(7): $1007-1012$.

Publish with Bio Med Central and every scientist can read your work free of charge

"BioMed Central will be the most significant development for disseminating the results of biomedical research in our lifetime. "

Sir Paul Nurse, Cancer Research UK

Your research papers will be:

- available free of charge to the entire biomedical community

- peer reviewed and published immediately upon acceptance

- cited in PubMed and archived on PubMed Central

- yours - you keep the copyright
BioMedcentral 